\title{
Strategies for translating metaphorical collocations in the Holy Qur'an
}

\author{
Hilal Alshaje'a \\ A Ph.D. Candidate, Dos in Linguistics \\ Kuvempu Institute of Kannada Studies \\ University of Mysore \\ Manasagangotri, Mysore- 570006
}

\begin{abstract}
A lot of research addresses to the definitions of collocations, their properties, and how they are different from other language forms like metaphors and idioms concerning the transparency of its adjacent constituents in contributing to meaning, both intra- and interlingually. Collocations in all languages including in Arabic, reflect conventional uses and fixed patterns, but the Qur'anic collocations show distinguished uses that are different from those existed in other Arabic genres. Thus, translating Qur'anic collocations in particular brings about a challenge because of linguistic, cultural, and communicative reasons. The present paper clarifies the distinguished characteristic of collocation in the Qur'an that makes its discourse incomparable in other languages such as English, and discusses the most appropriate strategies for rendering metaphorical collocations in the Holy Qur'an as well. Some translations of the Qur'anic text including collocation have been chosen as they display linguistic problems produced by cling on the part of the translators to the word order of the Arabic source text, thus causing eccentricity in the target language.
\end{abstract}

Keywords: collocations; metaphorical language; Strategies; translation; the Holy Qur'an.

\section{Council for Innovative Research}

Peer Review Research Publishing System

\section{Journal: Journal of Advances in Linguistics}

Vol 4, No. 3

editor@cirjal.com

www.cirjal.com 


\section{Introduction}

Collocations are notably available in all languages. Linguists provided varied and several definitions of collocations. Some scholars emphasize the multielement structure of a collocation, while others admit only those composed of pairs of words. Sinclair (1991), who is considered as one of the pioneering linguists, views a collocational structure as the co-occurrence of two or more words but within a short space of each other in a piece of discourse. Moreover, collocation is similarly could be defined as a sequence of two or more consecutive words with a special behavior in that it has the features of a semantic and syntactic unit, and whose obvious meaning cannot be elicited immediately from the meaning of its components.

Furthermore, what and how words collocate is a fundamental section of one's lexical knowledge which qualifies $\mathrm{him} / \mathrm{her}$ to identify the different senses of a word within a context, in addition to distinguishing a suitable lexical item that fits in the context under issue. therefore, this portion of linguistic knowledge has been broadly used in a assortment of natural language processing systems such as word sense explanation, Smadja (1993), information retrieval, Mitr et al. (1997) and machine translation, Gitaski et al. (2000) and Orliac and Dillinger, (2003: 292), to mention some.

Collocation is a problematic linguistic field because of vague their linguistic characteristics and unclear definition, the ambiguous difference between them and other linguistic expressions like idioms, in addition to their proliferation in all human languages. Sinclair (1991: 172) refers to the relative meaningfulness of components as a criterion in assigning the clarification of such two types of linguistic expressions. Idioms are explained as a single unit of meaning, which is autonomous of the meanings of its components.

Collocations in all languages including Arabic are of a formal and familiar utilization and recur in steady patterns, the present paper is dedicated to investigate some collocational occurrences in some Qur'anic texts that violate those steady patterns and deviate from the formal use that native speakers are familiar with.

Different features such as eloquence and culturality have made some Qur'anic collocations distinct and different from other types of collocations. The analysis and discussion of the examples below will examine the Qur'an eloquent particularity as a sacred text and the cultural dimension of some collocations that have made their translation into a different language very complicated. The study is based on some examples of the Qur'an where collocations are incorporated. In order to have a beneficial study, three authentic translations of the Qur'an are carefully chosen. Reference is made to some Qur'anic exegeses for understanding and discussing these examples linguistically and culturally.

\section{Strategies of translating collocations}

It is not easy to get the lexical equivalent of an item in translation when the translation is occurring between two different languages that do not have a common culture, such as the translation from Arabic into English and vice versa.

Baker (1992:47) states that conveying meanings that are ambiguous from an analysis of the individual constituent words or in collocations that are broadly arbitrary and language specific. By and large there is a recognition problem, since "recognition whether or not a collocation is familiar, natural, or just acceptable, is one of the important problems in translation" (Newmark, 1988:213).

Newmark (ibid) maintains that a key issue in translation is to find a convenient collocation. "Translation is sometimes a continual struggle to find appropriate collocations". Translators may encounter some obstacles and problems in rendering collocations; Baker (1992:54-61) enumerates these problems along with the strategies the translator should select in order to attain the closest equivalent of the SL item in the TL.

Newmark proposes the following strategies for every translator to follow when they approach translation:-

- Cultural equivalent:- In this strategy, the translator examines a TL cultural word for the SL cultural word. These cultural equivalents are extremely particular, i.e., belonging purely to the culture of that language, and the latter may not represent the exact equivalent.

-Through-translation:- This strategy includes the "literal translation of common collocations and names of organizations". Newmark argues that this procedure "should be used only when they are already recognized terms" (Newmark, 1988:85).

- Lexical synonymy:- During the procedure of translation, the translator may not find the precise TL equivalent for the SL item, thus $\mathbf{s}$ |he should choose a near TL equivalent (Newmark, 1988:84). This strategy, Newmark admits, "is only appropriate where literal translation is not possible and because the word is not important enough for componential analysis" (ibid: 88).

- Componential analysis:- "The splitting up of a lexical item into its sense components, often one - to - two, - three or - four translations" (ibid: 90). When the lexical item is significant in the text, i.e. it is a key-word; componential analysis is more prioritized than synonymy. (Newmark, 1981:31).

- Translation label:- A type of translation that should be made "in inverted commas" (Newmark, 1988: 90). Newmark (1981: 31 ) argues that in this strategy translation label is "sometimes proposed as a collocation in inverted commas .... Which may later be accepted". Baker (1992) argues that the use of these inverted commas is to draw the attention of the $S L$ reader to the TL writer's unusual image that he wishes to communicate to the SL reader. 
- Paraphrase:- Translators resort to this strategy when facing difficulties relating to translation of texts that have different cultures. Newmark (1988: 90) also calls this type free condition and claims that paraphrase is "the translator's resort". He restricts the use of this procedure to "anonymous text when it is poorly written, or has important implications and omissions".

- Reduction and expansion:- According to Newmark (1988:90), these two types of translation are "imprecise strategies" Baker (1992:77) suggests that a translator chooses the strategy of reduction when "a lexical item has no close match in the target language, its meaning cannot be easily paraphrased".

On the other hand, Newmark (1988:90) explains the strategy, namely, expansion as " a not uncommon shift, often neglected'.

- Transposition:- This strategy includes the replacing of one grammatical form by another. (Newmark 1981:31), and this because the "syntagm of the SL is either absent or rare in the TL".(Kuepper, 1977:247).

- Translation couplets:- The translator sometimes faces some cultural words that need more than one procedure to be translated. For instance. S|he may use "literal translation or translation label plus transcription"(ibid: 32 ). Or s/he may use the triplet, quadruplets procedures. (Newmark, 1988: 91) explains that the use of quadruplets is only with metalingual words.

- Modulation:- Vinay and Darbelnet firstly coined this term which indicates "a variation through a change of viewpoint, of perspective....and very often of category of thought" (Newmark, 1988:88). It includes "variation in point of view" (Newmark 1981:31). Modulation is of two types: standard modulation and free modulation. Translators usually use the second type "when the TL rejects literal translation" (Ibid).

\section{- Transference (loan words, transcription, and adoption) -:}

This is one of the most important strategies to which translators may resort when it is thought that SL element has no effective counterpart in the TL. Transference can be defined as the technique that involves the translator's incorporation of an SL element in the TLT. This procedure includes transliteration.

- Foot-notes and end-notes and glosses: - This is one of the most important strategies to which the translators resort when facing difficulties related to loss of meaning. They are 'additional information'; they come as additions to the TLT. They are of two types, foot-notes and end-notes. The translator may use foot - notes to express views and comments relating to any particular instance. Foot-notes are useful to introduce at the bottom of the page important explanations immediately required, but Newmark (1988:92) considers this type as nuisance when the notes are too lengthy and numerous. End - notes, on the other hand, are arranged in one order in one place. Glosses and prefaces are also important to the translator who opts for notes.

\section{3- Strategies of translating collocations of the Holy Qur'an}

(Newmark, 1988; Lorscher, 1991; Baker, 1992; Vinay \&Darbelnet, 1995) and other linguists examine quite the process of collocational translation. Their studies focused on the interconnection between the strategies utilized by translators and the hindrances faced in translation. Those studies adopt strategies of translation as solutions for solving translational problems. However, adopting specific strategies may lead to further obstacles and difficulties.

Newmark, (1988:8) has admitted translators should encounter obstacles at various levels, and thus produced specific strategies that enable the translator to overcome these obstacles, "when the translator is involved in the process of translation, he is always trying to solve a thousand small problems in the context of a large one". Getting the convenient collocations in translation is a "continual struggle" (ibid: 213). These cases could be solved when "translators depend on certain strategies, which may be quite effective when dealing with linguistic similarities but lead to serious problems in case of cultural disparity" (ibid: 81).

Furthermore, Newmark (1988: 45) has suggested specific methods of translation based on various recognitions of strategies. These strategies are, "word-for-word translation, literal translation, faithful translation, semantic translation, adaptation, free translation, idiomatic translation and communicative translation". Newmark affirms communicative translation in which the "translator attempts to render the exact contextual meaning of the original in such a way that both content and language are readily acceptable and comprehensible to the readership" (ibid: 47).

Baker (1992: 26-38) has listed eight strategies of coping with lack of equivalence at a phrase level. She proposed specific strategies such as superordinate, cultural substitution translation explanation, deletion and paraphrase.

For translating the collocations of the holy Qur'an, there are two main strategies. First the achievement strategies and secondly, the reduction strategy which involves both the avoidance as well as the deletion strategies. Translators who follow the "formal reduction strategies try to avoid producing non-fluent or incorrect utterances, and functional reduction strategies, which may include reduction of propositional content through topic avoidance, message abandonment or meaning replacement" (Ferch and Kasper ,1983: 52). On the contrary, in the achievement strategies, the "translator tries to expand his communicative resources with the use of achievement strategies which include generalization, paraphrase, word coinage, restructuring, co-operative strategies and non-linguistic strategies. Ferch and Kasper also refer to these achievement strategies as compensatory strategies" (ibid) 
The strategies used in the translation of metaphorical collocations of the Qur'an should necessarily be discussed. This pattern of collocations shows a serious problem to translators. In such a type, translators often fail to recognize the unusual combination of words, which are utilized in religious texts for stylistic and eloquent functions to create "images". It is what Baker (1992: 61) called "marked collocations". These collocations have comprehensive connotative metaphorical sense in addition to their denotative meaning. Consequently, selectional restrictions are violated and components of this type do not obey the semantic restrictions that other collocations obey.

Nontheless, "elements of metaphoric collocations are uniquely restricted to each other". (Baker, 1992: 61). The translator resorts to different strategies in the translation of this type of collocation which produce incorrect translation.

\section{1- Literal translation}

This strategy stands out as the most prominent strategy employed by the respondents to cope with the problem of translating metaphoric collocational patterns. Translators resort to this strategy because they hope to get one-to one similarity between SL and TL.

\section{2- Paraphrasing:}

This strategy causes the implied massage of the metaphoric message to be lost. nontheless, translators use it because they fail to attain the correct connotative sense of the word.

\section{3- Deletion:}

In this strategy, translators try to omit huge parts of the source message because of the lack of understandability of semantic parts.

In order to check out the soundness of these strategies; a study of three translations of Qur'anic collocations in the Glorious Quran and the way their translation was handled, is made in the following examples.

SL (1):

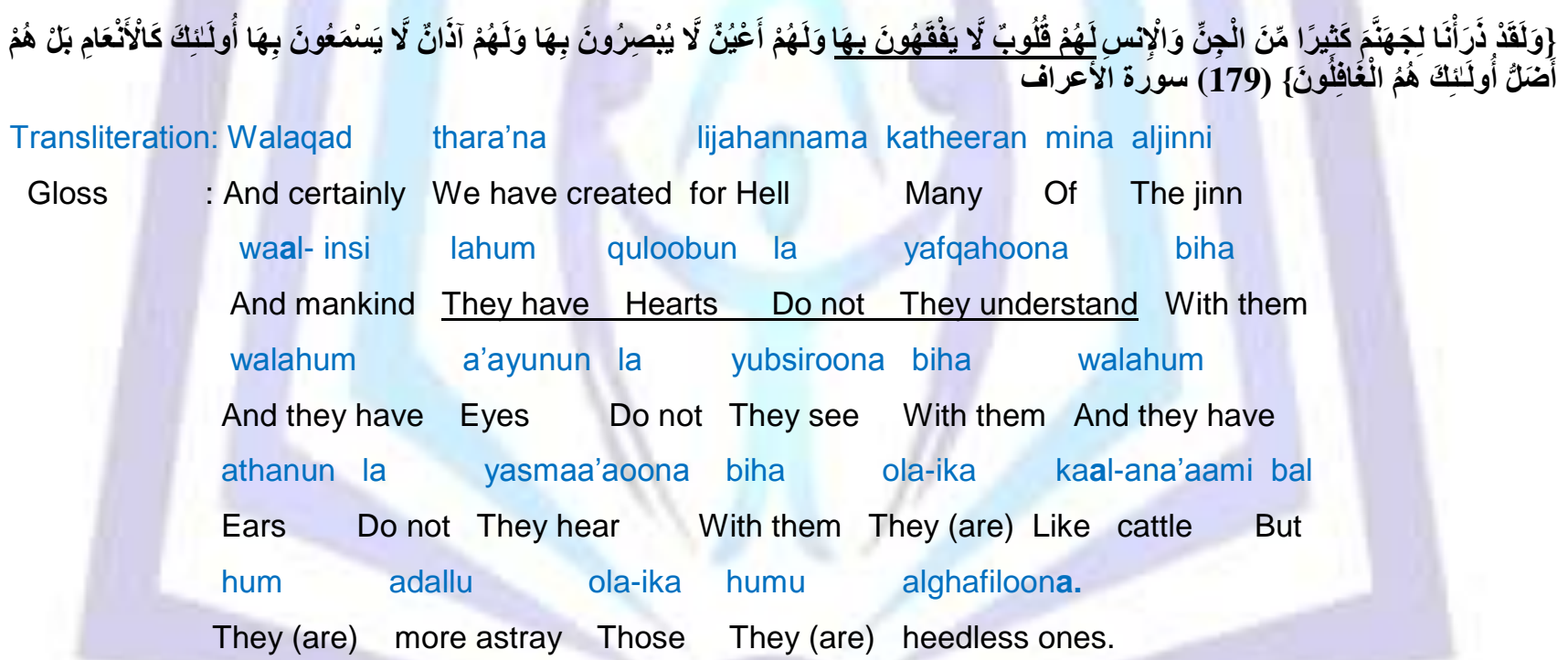

\section{TL Texts:}

\section{1- Pickthall (1938:52)}

Already have We urged unto hell many of the jinn and humankind, having hearts wherewith they understand not, and having eyes wherewith they see not, and having ears wherewith they hear not. These are as the cattle nay, but they are worse! These are the neglectful.

\section{2- Ali (2007:82)}

Many are the Jinns and men we have made for Hell: They have hearts wherewith they understand not, eyes wherewith they see not, and ears wherewith they hear not. They are like cattle,- nay more misguided: for they are heedless [of warning].

\section{3- Arberry (1988:107)}

We have created for Gehenna many jinn and men: they have hearts, but understand not with them; they have eyes, but perceive not with them; they have ears, but they hear not with them. They are like cattle; nay, rather they are further astray. Those--they are the heedless.

\section{Discussion:}


This verse talks about "those who are heedless of the signs God has placed in the universe and in life itself, and choose not to reflect on the events that take place around them, and do not see God's will behind them all, are indeed further astray than cattle. Animals have natural tendencies to guide them. Human beings and jinn have been given hearts, minds, eyes and ears to hear, look and understand. If they choose not to open their means of perception, and prefer instead to go about life without reflecting about its meaning and aim, and without looking at its events and what they signify, or hearing its messages, they place themselves below animals that have only been given their natural tendencies. As a result, they are destined for hell (Qutb, 2004, vol. 6: 231-32).

Since Larson (1988:155) states that collocation is concerned with how words go together, i.e., which words may occur in constructions with other words, the meaning of the whole collocation are based on its two parts. There is no any doubt that understanding is associated with minds or brains as the brain is the source of information analysis and interpretation while the heart is the place where emotions and feelings lie. In this collocation, there is a linguistic rhetorical feature of the Qur'an lies in the association between the heart and understanding. It might also be possible that the hearts may have cells which have something to do with brain and understanding, a fact that might be scientifically demonstrated in the future.

A translation challenge may arise when people come across the reading of the collocation wherein 'understanding' usually collocates with the brain and not with the heart. The translator should take into consideration this linguistic fact and explain it in a footnote or in the body of the translated text. The three translators have translated the collocation similarly, depending on the verbal context of the source text, where the heart is unable to recognize what is right (al-Fīrūzabādī, 2013:179; al-Maḥallī and al-Suyūțī, 2007:180; Ibn Kathir, 2009, vol. 3:513). All translators render the collocation literally, maintaining the form and the meaning of the collocation since the literal translations of the collocation would not misguide target language readers. However, ignoring the real communal relationship between the two parts of the collocation could be considered as a shortcoming of the translations. Translations could have been supported with explanatory details that manifest the harmony between conception and the organ in which the process takes place.

$\underline{\text { SL (2): }}$

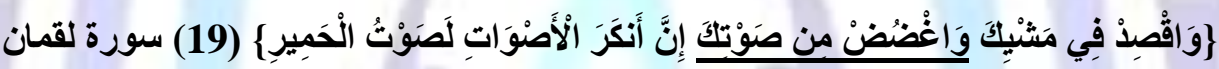

Transliteration: Waiqsid fee mashyika waoghdud min sawtika inna

Gloss : And be moderate In Your walking And lower of Your voice Verily

ankara al-aswati Lasawtu alhameeri.

The hardest all voices the voice of the donkey.

\section{TL Texts:}

\section{1- Pickthall (1938:131)}

Be modest in thy bearing and subdue thy voice. Lo! in harshest of all voices is the voice of the ass.

\section{2- Ali (2007:208)}

"And be moderate in thy pace, and lower thy voice; for the harshest of sounds without doubt is the braying of the ass."

\section{3- Arberry (1988:248)}

Be modest in thy walk, and lower thy voice; the most hideous of voices is the ass's.'

\section{Discussion:}

In this verse, Luqmān admonishes his son, speaking about "the manners that should be characteristic of advocates who call on people to adopt the divine faith". Of those characteristics is to walk in a proper way and "to lower his voice, which is a mark of politeness, self-confidence and reliability. Only an impolite person, or one who has self doubt or uncertainty about what he says, resorts to speaking loudly as he tries to disguise such doubts by raising his voice" (Qutb, 2004 , vol. 13: 334-35).

As a matter of fact, translating this type of collocation brings about some translation problems; especially for the reader whose mother tongue is the source language; the semantic or the linguistic dimension of the collocation do not create this understanding problem, but rather the social restrictions or constraints. "In other words, the text is socially bound and is thus social specific. Similarly, translation can provide the reader with the real meaning of the pair of collocation which was until very recently a form of misconception or misunderstanding. Target language readers, whose mother tongue is not Arabic, would not face misconception problems as the exact meaning is relayed and at the same time do not have any social background of the communal use of the collocation; to put differently" (Al-Quran \& Al-Azzam, 2010)

Collocations have an arbitrary and fixed relationship due to the current and frequent use of some co-occurring

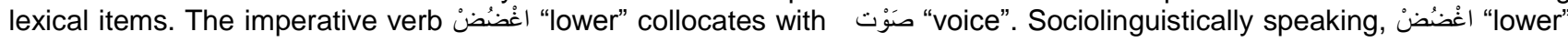
usually occurs with the "the eye" or "sight". The habitual frequent and the recurrent use of this collocational couplet has given its components a certain social identity, which makes the occurrence with other, though correct items, strange. In 
other words, the social power given to the collocational pair cannot be easily disintegrated or separated, as the pair is socially intertwined and audio woven.

(Larson, 1988:155) mentions that knowing which words go together is an important part of understanding the meaning of translating it; this fixed combination is fully understood by the three translators even though they do not belong to the same culture of the source text. Thus, the three translations have succeeded in relaying the exact semantics of the source text 'to lower down' or subdue' (Ibn Kathir 2009, vol. 6:339; al-Fīrūzabādī, 2013: 466), though no reference is made to the sociolinguistic imposition of the collocation.

\section{SL (3):}

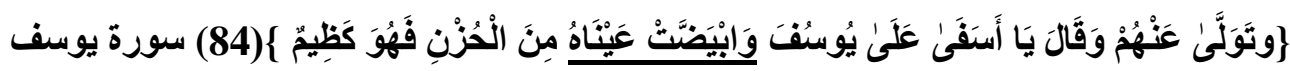

Transliteration: Watawalla

a'aanhum waqala ya asafa

a'aala yoosufa

Gloss

: And he turned away From them And said Alas! My grief For Joseph

waibyaddat a'aaynahu mina alhuzni fahuwa

And all were whitened His eyes because of The sorrow that he katheemun.

was suppressing.

\section{TL Texts:}

\section{1- Pickthall (1938:74)}

And he turned away from them and said: Alas, my grief for Joseph! And his eyes were whitened with the sorrow that he was suppressing.

\section{2- Ali (2007:116)}

And he turned away from them, and said: "How great is my grief for Joseph!" And his eyes became white with sorrow, and he fell into silent melancholy.

\section{3- Arberry (1988:146)}

And he turned away from them, and said, 'Ah, woe is me for Joseph!' And his eves turned white because of the sorrow that he choked within him.

\section{Discussion:}

In this verse "an inspirational portrayal of a bereaved father. He feels that his tragedy is all his own. No one around him shares in his distress or feels his pain. Hence, he moves away to nurture the loss of his beloved son, Joseph, whom he has not forgotten despite the passage of so many years. Indeed time has not reduced his sorrow; it has all been brought back to life by the new calamity involving his youngest son, Joseph's younger brother. But he soon suppresses his sorrow and hides his feelings. As his intense grief and sadness are suppressed, his eyes lose their sight" (Qutb, 2004, vol. 10: 104).

Ibn Kathir (2009:405/4); al-Fīrūzabādī (2013:253); and al-Maḥallī and al-Suyūțī (2007:252) state Ya'qub's eyes turned white; he lost his sight because of the sorrow that he was suppressing.

Rendering such type of collocation causes some translation problems, particularly for the reader whose mother

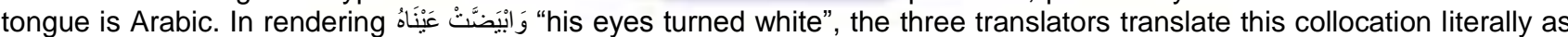
"his eyes were whitened", "his eyes became white", and "his eyes turned white". When the verb ابيض "whiten" collocates with face or eyes, it acquires a metaphorical meaning "becoming blind". Thus, All translators have failed to recognize collocational range of the verb ابيض 'whiten' and its meaning that is far remote from the most frequent meaning which denotes the colour white as in "white walls".

\section{SL (4):}

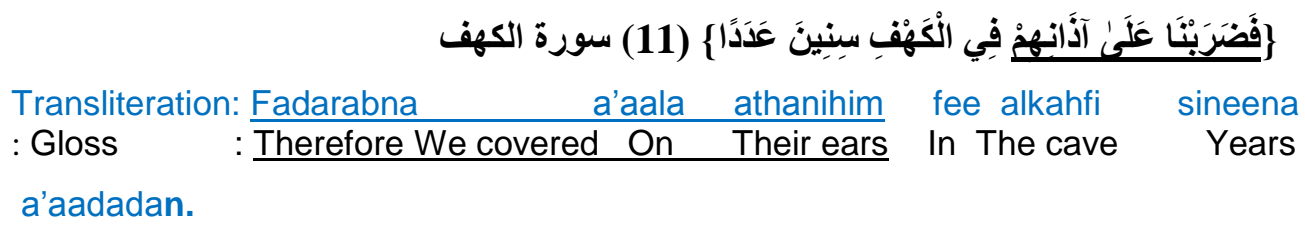

A number of . 


\section{TL Texts:}

\section{1- Pickthall (1938:90)}

Then We sealed up their hearing in the Cave for a number of years.

\section{2- Ali (2007:142)}

Then We draw [a veill over their ears, for a number of years, in the Cave,[so that they heard not]:

\section{3- Arberry (1988:174)}

Then We smote their ears many years in the Cave.

\section{Discussion:}

This verse states that "the people of the cave were made to sleep in the cave for a number of years, which is not stated here" (Qutb, 2004, vol. 11: 195).

When the verb ضَرَب "smote" collocates with the noun آذَانِ "ears" does not give a literal meaning (i.e. to smote), but rather a metaphorical one. Such a lexical item shows heavy sleep and more impressive than the use of the simple verb أنام "make them sleep"

In rendering the collocation فَضَرَبْنَا عَلَى آَذَانِهِْ "We smote their ears", translators paraphrased this collocation because they are unable to produce the correct connotative sense of the verb "ضَرَّ"smote". Therefore, received paraphrases like, "we sealed up their hearing", "we draw [a veil] over their ears", and "we smote their ears" reveal a loss of the semantic message which is "they went into deep sleep (Al-Fīrūzabādī, 2013:313; al-Maḥallī and al-Suyūțī, 2007:312; and Ibn Kathir , 2009:139/5). Thus, all translators fail to produce an appropriate translation for this collocation.

\section{SL (5):}

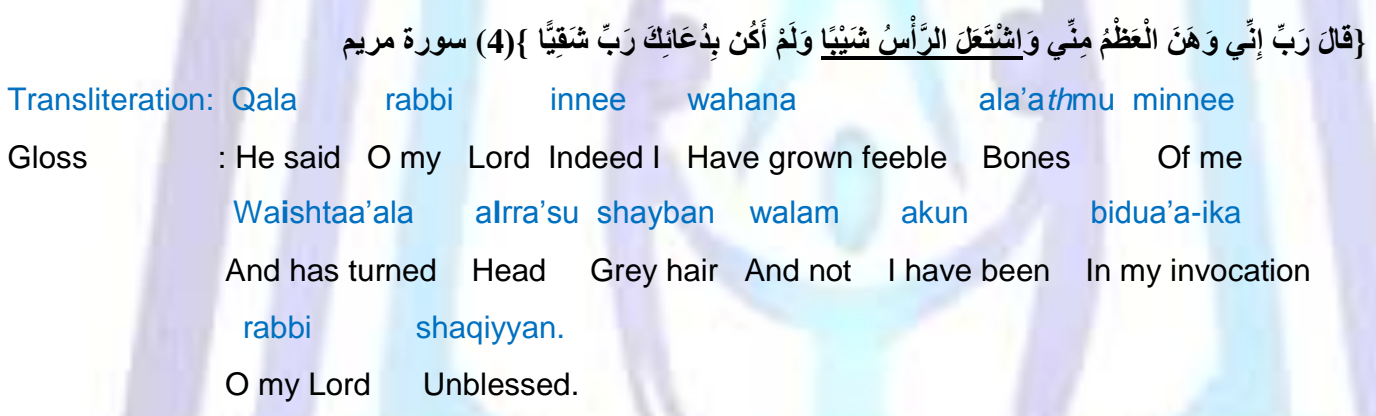

\section{TL Texts:}

\section{1- Pickthall (1938:94)}

Saying: My Lord! Lo! the bones of me wax feeble and my head is shining with grey hair, and I have never been unblest in prayer to Thee, my Lord.

\section{2- Ali (2007:148)}

Praying: "O my Lord! infirm indeed are my bones, and the hair of my head doth glisten with grey: but never am I unblest, O my Lord, in my prayer to Thee!

\section{3- Arberry (1988:180)}

Saying, ' $\mathrm{O}$ my Lord, behold the bones within me are feeble and my head is all aflame with hoariness. And in calling on Thee, my Lord, I have never been hitherto unprosperous.

\section{Discussion:}

In this verse, "Zachariah complains to his Lord that his bones have become feeble, and when bones are feeble, the whole body is weak. After all, the bones are the stiffest part of the body. They form the skeleton which the muscles flesh up. He also complains that his head glistens with grey hair. The Qur'ānic expression here, ishta 'ala al-ra'su shaybā, shows the greyness of hair like a fire being ignited, and the man's head covered with this fire, so as to leave no black hair. Both feeble bones and grey hair signify old age and the weakness associated with it. It is this weakness that is the subject matter of Zachariah's complaint as he presents his case, and his hopes, to his Lord. He then makes a clear acknowledgement" that "He is used to having his prayers answered. He was not disappointed when he prayed to Him in his time of strength and vigour. Now in his old age and weakness, the need for his prayers to be answered is even more pressing" (Qutb, 2004, vol. 11: 263).

Al-Mahallī and al-Suyūțī (2007:327); Ibn Kathir (2009:212/5); and al-Fīrūzabādī (2013:326); say the meaning of this collocation is that the gray hair has burned into the black hair. It is intended to inform of weakness and old age. 


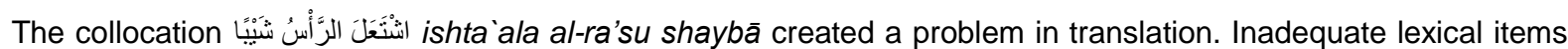
"is shining", " doth glisten" , "aflame" all of which belong to one semantic field that conveys a sense of brightness which in fact cannot be applicable here and do not express the meaning of "iَنَتَ "flame" in this collocation. The metaphorical use here indicates that grey hair has covered all of the head so there is no black hair left just like the burning process where the fire eats up everything so there is nothing left. Thus, the translators failed to recognize the selectional restrictions of

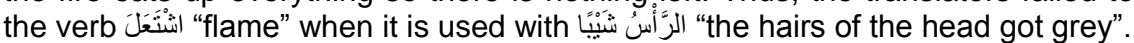

\section{4- Conclusion}

Many translation problems usually emerge because of cultural, linguistic and communicative reasons. The demonstrative examples of the study illustrate that the Qur'anic Arabic is distinguished because of the way the collocations are employed. Moreover, the study has manifested that linguistic problems emerge in a contrastive linguistics study, where the order of the constituents of the collocations varies, which could be referred to the cultural and social influences. As a result, the translators have stuck to the word order of the original text that, in turn, leads to some peculiarity and oddity in the target language.

It seems that the translators use both literal and paraphrasing strategies in rendering metaphorical collocations in the holy Qur'an. Literal translation may produce unsuitable translation if a translator translates metaphorical collocations literally without paying attention to the intended meaning. Thus, the message implied is probably not conveyed due to the translator's failure to recognize it. Then, the translation will be unsuccessful because the connotations are completely lost to the majority of the receptive language readers; however, translators should sometimes opt for the strategy of literal translation or to the strategy of paraphrasing when translating metaphorical collocations.

\section{References}

Al-Fīrūzabādī, M. (2013). Tanwīr al-Miqbās min Tafsīr lbn 'Abbās. Translated by Mokrane Guezzou. Jordon: Royal Aal al-Bayt Inistitute for Islamic Thought.

Ali, A. Y. (2007). The Holy Qur'an: Text and Translation\& Commentary. Kuala Lumpur: Islamic Book Trust.

Al-Maḥallī. J \& al-Suyūțī. J. (2007). Tafsir al-Jalalayn. Translated by Feras Hamza. Jordon: Royal Aal al-Bayt Inistitute for Islamic Thought.

Al-Quran, M and Al-Azzam, B. (2010) Collocational Distinct Uses in Qur'anic Arabic, Journal of Literature and Language. "Progress" Academic Publishing House: Azerbaijan.

Arberry, A. J. (1988). The Koran Interpreted: A Translation. Oxford: Oxford University Press.

Baker, M. (1992). In other words: A coursebook on translation. New York: Routledge.

Ferch. \& Kasper, G. (1983). Strategies in interlanguae communications. Harlow: Longman.

Gitsaki C. et al. (2000). English Collocations and Their Place in the EFL Classroom, pp. 121126.

Ibn Kathir, al-hafiz. (2009). Tafsir Ibn Kathir. Translated by Muhammad Saed Abdul-

Rahman. United Kingdom: MSA Publication Limited.

Kuepper, K. (1977). Literary Translation and the problem of equivalency. Meta, 22 (4), 243

251.

Larson, M.L (1988). MeaningBased Translation.University Press of America Inc. New York.

Mitra et al. (1997). An analysis of statistical and syntactic phrases. In Proceedings of RIAO,

200-214

Newmark, P. (1981). Approaches to Translation. Oxford: Pergamon Press.

Newmark, P. (1988). A textbook of translation. London: Prentice Hall.

Orliac, B. \& Dillinger, M. (2003). Collocation extraction for machine translation. In

Proceedings of Machine Translation Summit IX, 292-298.

Pickthall, M.M. (1938). The Meaning of the Glorious Qur'an: Text andExplanatory

Translaion. Hyderabad: Deccan.

Qutb, S. (2004). Fi Zhilalil-Qur'an.Translated by As'adYasin and et al. Jakarta: Gemalnsani 


\section{Press:.}

Sinclair J. (1991). Corpus, Concordance, Collocation. Oxford: Oxtbrd University Press.

Smadja. F. (1993). Retrieving collocations from text. Xtract, Computational Linguistic, 19 (1), 143-177.

Vinay, Jean-Paul \& Darbelnet, Jean Louis. 1995. Comparative Stylistics of French and English: a Methodology for Translation. Philadelphia: John Benjamins. 